\title{
Javanese Proverbs As Social Control And Human Character Imageries (Textual And Contextual Understanding)
}

\author{
Sumarlam \\ \{sumarlamwd@gmail.com\} \\ Javanese Language and Letters Department, Faculty of Cultural Sciences, Sebelas Maret University
}

\begin{abstract}
Javanese proverbs (including paribasan, bebasan, saloka, pepindhan and sanepa) have their own uniqueness, in terms of the form, function and meaning. Javanese proverbs illustrate both good and bad characters inherent in Javanese people. The portrayal of good character is intended as an exemplary which enables human's hearts incline towards imitating good characters and emulate good characters; while the depiction of bad characters concerns a warning to humans in order not to take exemplary of the bad characters, to avoid despicable characters, and eliminate the object characters inherent in them. In this case, Javanese proverbs as a text describing about good and bad characters, while characters, characters, behaviors that are social realities inherent in humans and which occur in society are the context. It is logically and empirically proven that context always precedes the text. In addition, Javanese proverbs function as persuasive social controls. That is, the Javanese proverb serves to control, thus the Javanese would imitate and emulate the good characteristics, attitudes, behavior, character running the social lives; in addition to avoid the bad characteristics, behavior, attitudes, and character. By understanding proverbs, we will know human nature and character".
\end{abstract}

Keywords: Javanese proverbs, human characters, text, context, social control

\section{Introduction}

Javanese proverb is a typical Javanese language in use which should interestingly be studied for its unique and specific nature. Among the highly interested aspects to be concerned about the Javanese proverbs are the needs to examine it from both the linguistic, literary, and cultural aspects.

One of the contextually real samples is a conversation occurred between the members of Sebelas Maret University (UNS) Senate, where mostly of them are joined by professors. This dialogue was initially started by Prof. Darsono (Vice Rector III of UNS for the period 2014 2019) who posted an article entitled "Jokowi dan Kekuasaan Jawa" [Jokowi and Javanese Power]" by Eko Sulistyo [1], Deputy of Political Communication and Information Dissemination of the Presidential Staff Office. In his article posted in Harian Tempo (August 2, 2019), Eko Sulistyo considered that "Seno Gumira Ajidarma worried about President Joko 
Widodo's expression in Javanese language, Lamun sira sekti, aja mateni; Lamun sira pinter, aja minteri; Lamun sira banter, aja mbanteri as a form of political-cultural arrogance."The Javanese philosophical expression or piwulang does not mean he wants to act like Javanese kings with unlimited power. In fact, the phrase reminds us all that such power is limited, neither it is absolute, nor it can be misused since it is regulated by law.

Seno's concern, continued to Eko Sulistyo, both explicit and implied, regarding Jokowi's leadership message was certainly legitimate. Especially if it is associated with today's political context, the phrases as Lamun sira sekti, aja mateni shows the character of Jokowi's leadership as a solidarity maker, a leader who has the spirit to embrace and unite. Despite being re-elected as president, Jokowi did not underestimate the defeated. In a speech by Visi Indonesia in Sentul, Bogor, some time ago, Jokowi highlighted that being a very noble opposition. The words of a re-elected president are always interesting to interpret and discuss. However, a good interpretation shall not only observe either at the spoken word or text, but one should also consider the context.

The development of interpretation on the meanings of proverbs additionally occurred in Indonesian proverbs as Kusno (2015) commented [2]. Gustaaf Kusno believes that of the thousands of Indonesian proverbs there are a number of metaphors (problems) with our common sense. Accordingly, it is logical, as it should be, it should be "Habis manis, sepah dibuang" [Literally, leaving after having fun], instead of saying "Habis manis, sepah ditelan" [after having the sweetness, the remains is swallowed". Another Indonesian proverb being sued by Kusno, i.e., "Sambil menyelam, minum air" [equally trans. into English, "to kill two birds with a single stone']; "Nasi sudah menjadi bubur" [equally trans. into English, 'it's no use crying over spilt milk'] "Guru kencing berdiri, murid kencing berlari"; [equally trans. "teachers are the role models for their students] "Hangat-hangat tahi ayam" [literally, as hot as a chicken dung] instead of "as hot as a horse dung" or " as hot as cow dung"; and "Lidah tak bertulang"[literally, boneless tongue].

Among the studies on proverbs (Javanese, Sundanese, Minang, Indonesian) have been carried out by several researchers, Setyaningsih studied "Pepindhan in Javanese Human Activity, the study aims to describe the typical forms of pepindhan on human activity, to seek out the comparative objects of pepindhan in human activity, and describe the cultural elements reflected from the vocabulary use in the pepindhan [3].

The Javanese moral message, "Wani Ngalah Luhur Wekasane" in the Javanese novel Candhikala Kapuranta as Satiyoko discussed. The moral message "wani ngalah luhur wekasane" is spiritual behavior in the context of Javanese logic. The phrase means to achieve an ideal it requires a struggle followed with having the attitude of humility, succumbing not to lose, and not underestimate and sacrifice others [4].

Setiyanto studied the hortatory discourse of the Javanese language on ular-ular, the slot and slot structure study. The ular-ular discourse is considered productive, often time it used in marriage processions. Three important aspects highlighted in the study are the slots that construct ular-ular discourse, the slots structure of ular-ular discourse, and functions of each slot [5].

The comparative language style in the song lyrics of Cianjuran: the Sundanese people's character expressions in the West Java were thoroughly studied and academically explained by Darheni. This study aims to describe (1) the beauty of comparative language styles in Cianjuran song lyrics, which covers metaphor, simile, and personification, and (2) the themes in the song lyrics. The study shows significant implications as the efforts in maintaining the mother tongue (the Sundanese language) in the West Java through preservation, enjoyment, 
creation, and creativity of the lyrics which enables it to develop noble values of the national culture as an expression / reflection of the national identity [6].

Almos, Pramono, and Reniwati explored pantun 'rhythmical poems' and the Minangkabau sayings framed with both flora and fauna contexts. This study concluded that there are a lot of flora and fauna texts found in the Minangkabau pantun and sayings. Their contents teach humans in terms of doing good, patience, advice, perseverance, and truth. In the rhytmical poems and sayings there are manifested wisdoms and rules of high value for the benefit of living in the Minangkabau society [7].

In addition to local languages, the studies on the Indonesian proverbs or idiomatic expressions have also been investigated by Abdul Khak. This study concludes that based on structure, the Indonesian idioms are distinguishable into three types; they are idioms structurally realized in complex words, phrasal idioms, and idiomatic expressions (proverbs) with various meanings [8].

From some of the aforementioned relevant studies, current study, entitled "Javanese Proverbs as Social Control and Human Character Imageries (Textual and Contextual Understanding)" has not been studied by previous researchers.

Having studied from the linguistic aspect, Javanese proverbs share a distinctive structure, the order of the constituents can neither be rearranged, nor can the elements be substituted with other synonymous elements. From the literary aspect, Javanese proverbs shares stylistic and aesthetic elements which in essence are different from other forms of literary work. The language and diction remains unique. Javanese proverb is a type of language use which interestingly needs to be examined from its cultural aspect since those Javanese proverbs were initially produced in Javanese social and cultural settings. Both Javanese culture of moral teachings and values are often time transmitted communicatively through Javanese proverb expressions. Likewise, the Javanese social ethics and norms which reflect the principle of harmony in the Javanese individuals' lives, the Javanese proverbs enable people across generations bridge the communication subtly. More specifically, Javanese proverbs effectively functions to describe situation, qualities, attitudes, character / nature, trait, and behavior of Javanese people in their social lives, in addition to describe the natural situation and state of an object.

\section{Research Method}

This paper reveals a handful of Javanese human nature or character reflected in Javanese proverbs. However, before arriving at the description of human characters in Javanese proverbs, this section begins to explore the Javanese proverbs, human characters, and texts and contexts as a theoretical basis; which ends with the research method.

\subsection{Javanese Proverbs}

In Kamus Linguistik, Kridalaksana provides a limitation on proverb as a sentence or fragment of a sentence that has frozen form, meaning, and function in society, is hereditary, used to decorate essays or conversations, reinforce the core intent of an essay, in addition to reflect advice, teaching or living guidelines [9]. From this definition the following proverbs can be derived: (1) proverb is in sentence or fragment form of sentence its, (2) form, meaning, and function are frozen, (3) hereditary, (4) it mainly functions as decorating essays, reinforcing intentions, giving advice, teaching, and life guidelines. The characteristics on (2) 
and (3) show that proverbs, both form (structure), meaning, and function, are frozen: steady, solid, constant, unchanging. Thus, from the beginning to current times, the number of proverbs remains the same; and their meaning and function remains unchanged and hereditary passed down. Even though languages develop in its nature, and vocabulary always increases, proverbs neither develop nor increase. This is why some would call proverbs are frozen.

Proverbs in Javanese are classifiable into six types, namely paribasan, bebasan, saloka, pepindhan, sanepa, and isbat [10]. The differences in the six types of proverbs are noticeable in the examples presented in this paper.

\subsection{Human Character}

Kamus Besar Bahasa Indonesia explained the notion of character as an idea of mental characteristics, morals or character which distinguishes one person from another. Character also means trait or quality [11]. Thus, having character means having quality, having personality; and it additionally means trait or nature.

There are various characters, traits or human characteristics where they are describable or expressed through proverbs. Human characters are basically classifiable into two kinds of categories, the first is a good and the second is the bad characters. Good character is a character that tends not to harm others or himself, i.e., simple, humble, fair, wise, clever, honest, conscientious, opinionated, love to help, love of others, etc. Meanwhile, bad characters are characters which tend to be harmful for self or the others; i.e., greedy, covetous, or acquisitive, love of fighting, love of instigating between conflicting parties, arrogant, bigmouthed, having a lot of promises but none of which is truly realized, love of being praised, like to criticize others, love of prosecuting others, miserly, stiff, clumsy, lazy, love of doing fun, love of cheating, careless, love to hurt other people, love to curse, love of being masher, etc. The portrayal of both good and bad characters is inherent in human beings, where in Javanese proverbs they are sometimes expressed with intentions. The portrayal of good character is intended as exemplary, it is an effort made since human heart by nature is inclined moving towards emulate good characters and emulate these praiseworthy characters. Meanwhile, the depiction of bad characters is intended as a warning (Javanese: peling) to humans which help them avoiding to imitate bad characters, avoiding despicable characters, and throwing away the despicable nature inherent in them.

\subsection{Text and Context}

Language studies need to consider the context of human language and aim to improve or actualize the main function of language, namely the function of communication. With regard to the core function of language, in his "exploration" Sudaryanto came to the conclusion that the essential function of language is as a "developer of reason" and "maintainer of cooperation" [12].

Understanding a text apart from its context of situation is as if, understanding the language apart from humans who speak the language and society where humans live and hold social interactions. Thus, such an understanding will last meaningless, since nothing but understanding language which does not function in this life.

Text is language, both oral and written, or forms of means used to express whatever we think, which functions. The functional language according to Halliday is nothing but the language which carries out certain tasks in its contextual situation. The fact that all languages must be understood on its contextual situation, it is applicable to every group of people who live at every level of human development [13]. 
There are two typical understandings of a language; one is the contextual of language and the other is the contextual beyond the language. Texts which can either be in the form of words or sentences, in which they exist around the main text being studied is the so called linguistic contexts. Meanwhile, the environment which exists beyond the text, however, is still related to the text being studied, including the socio-situational and cultural factors, called extra-linguistic-context. Malinowski, an anthropolinguistic expert, refers to such external contexts is called "contextual situation".

Understanding both text and context shall further strengthen the belief that in understanding, observing, and studying phenomena beyond the language, expressed through language, many of instructions we obtained are explainable, by moving out of our language we are able to explain the meanings of the language. Thus, in a complete description of a language it is necessary to provide a description about the socio-cultural background associated with it.

Based on the concepts and views elaborated in this paper, it seems that Javanese proverbs are one of the Javanese texts, while human character is one of the situational contexts surrounding these texts. The thing to remember is that in real life the context generally always precedes the text. The situation exists earlier than the text related to the situation. In other words, the character, trait, quality, attitudes and nature of human beings first existed and were owned by humans before the text was compiled in proverbs forms. The good character of humans comes before a proverb is created which describes the nature of it. And vice versa, the bad character inherent in human beings first exists, and then a proverb is created which meaning is in line with the character which describes it.

Language does have the power to educate, move the soul, foster attitudes, qualities, and human character, discover what is revealed and hidden in itself, and has power as social control. In this case, two types of social control can be distinguished, namely Coercive Social Control (CSC) and Persuasive Social Control (PSC). The first type of social control, CSC, is direct and strict social control, commonly accompanied by social coercion and sanctions for violating them, i.e., the law. The second type of social control, PSC, is social control that takes place persuasively, indirectly, and moves slowly; i.e., moral values, customs, religion, good behavior patterns according to society's shared perceptions, etc [14]. In this case, the social control function of language applies at the second level of social control, namely persuasive social control. Thus, the Javanese proverb that functions to control, which expect that the Javanese would take exemplary from the characteristics, behavior, qualities, trait, good characters practice in this life; in addition to remove and avoid bad traits, behavior, character, qualitoes, and characters are social controls of language transmitted persuasively to individuals or Javanese society. In sociolinguistics there is a classic expression about the strategy of managing a language, "If you want social stability, understand language." This expression is applicable in the strategy of managing proverbs, "By understanding proverbs (paribasan, bebasan, saloka, pepindhan, and the like), they enable us to know about the humans' nature and characters".

The research data was in written data of Javanese proverbs expressions. The data were obtained from various written data sources; among others are the written documents in the form of books, Javanese proverbs, diction and utterances written in Whatsapp which contains the Javanese proverbs.

The data collection methodologically used the attentive observation and note taking techniques. That is, the written data were primarily obtained by attentively listening to the written language directly following a procedure (1) reading sentences of Javanese proverbs at the specified data source; (2) signing the highlighted sentences with certain marks; (3) taking 
note on the data which have been marked; (4) doing data selection and data classification; and (5) certainly continued with data analysis process.

The data analysis followed Sudaryanto's model of distributional (agih), and identity (padan) methods [15]. The agih method is used to analyze the Javanese proverb data following with the techniques of deletion, substitution, and reverse. Meanwhile, the equivalent method used in this study is the translational equivalent and referential equivalent methods. The analysis technique used is Immediate Constituent Analysis technique, namely the data analysis technique by sorting the linguistic units analyzed by a determinant in the form of the researcher's mental sorting force. In addition, the data were analyzed contextually to understand the good and bad characters of humans in their social lives as contexts reflected in Javanese proverbs as texts.

\section{Results And Discussion}

\subsection{Human Character Imageries in Javanese Proverbs}

As explained in the previous section, various human characters expressed in Javanese proverbs can basically be classified into two kinds of characters, namely bad characters and good characters [16]. The Javanese proverb describing these two human characters is described in the following section.

\subsection{Bad Character}

Javanese proverbs that describe humans' bad characters; among others found in paribasaan, bebasan, saloka, pepindhan, and sanepa below.

(1) Sapa sira sapa ingsun 'who are you who am I'

(2) Kakung adiguna 'men rely on intelligence'.

(3) Kurang ulat

'careless'

(4) Kakehan kresek 'too much noise (like dried leaves being trampled)'

The four examples of paribasan above refer to the bad humans' characters, as seen in the words formation. Example (1) Sapa sira sapa ingsun 'who are you who am I' refers to an arrogant individual, they are the people who dislike to socialize with others of socially unequal to them, i.e., a royal family who does not want to get along with people from commoners. An official who only wants to get along with other officials and feels it is inappropriate to associate with people who are not officials. Likewise, the rich people feel unworthy to associate with the poor, etc. Such character certainly should never be appreciated for it will only create a deeper gap between the two groups.

Let us now consider the other bad characters revealed by the following bebasan.

(5) Kegedhen endhas kurang utek

'too big head less brain'

(6) Mumbul-mumbul kaya tajin

'boasting like water starch (rice)'

(7) Kendho tapihe

(8) Ngrabekake mata 'saggy cloth' 'mating the eyes'

These four bebasan examples refer to bad character. Example (5) refers to individual's character of arrogant, overbearing, or haughty. This bad character is depicted with a quite large head, but a small brain. 
Many of bad human characters are expressed through saloka. Consider the following four examples.

(9) Jurang grawah ora mili 'A wide and deep cliff but the water does not flow'

(10) Sumur lumaku tinimba 'Walking well to be bailed out'

(11) Durga angangsa-angsa 'Durga the gluttonous'

(12) Gajah alingan suket teki 'Elephants take refuge in puzzle grass'

The example (9) refers to a parable of a man with a lot of promises, which is likened to a jurang grawah 'wide and deep cliff', however, ora mili 'does not flow (water)'. Thus, what is referred to by such bebasan is a person who has the nature or character of love to break promises. This typical bad character does not only harm the person himself, it is also harmful to others.

The following four examples are the Javanese pepindhan which express human bad characters.

(13) Kaya mutung-mutungna wesi gligen

(14) Anggedebog bosok

(15) Anggenthong umos

(16) Kaya ngandhut godhong randhu

'be likened to break an iron bar'

'be likened to rotten banana stems'

'be likened to a leaking jar'

'be likened to pregnant the leaves of randu'

Example (13) is pepindhan which refers to the character of an arrogant person, who likes to brag or is big-mouthed. An individual who shows a very arrogant character is likened to being able to break an iron bar (Kaya mutung-mutungna wesi gligen).

Human bad character can also be expressed with sanepa as shown in the following two examples.

(17) Cumbu laler 'tame flies'

(18) Mundur unceg 'back borers'

From the two examples of sanepa element above, they referred to individual's character of extraordinarily wild (17), and the individual's character of extraordinarily harsh (18). The wild a laler 'fly' as an exemplary (17) is a typical tame (cumbu) compared to the character it refers to. Thus, those sanepa actually refer to wild characters or behavior that greatly exceeds the wild flies.

\subsection{Good Character}

The Javanese proverbs as a text which refers to or depicts the context of human good character, among others, the paribasan, bebasan, and Saloka as follows.

(19) Wani ngalah luhur wekasane 'Dare to succumb good (noble) at the end'

(20) Tega larane ora tega patine 'can stand the pain but can't the death'

(21) Titi mantri

(22) Nglelemu satru

'conscientious minister

'fatten up the enemy'

In the four examples of paribasan above it can easily be seen which good character does it refers to. The good character referred to by example (19). Having the character of succumb (wani ngalah) is exemplified with (19). The character loves to succumb is believed to be a good character for the Javanese. Such character is not detrimental to either other people or oneself, because the Javanese people believe that by losing, they will get the good, which is luhur wekasane. Individuals with character of love to succumb, i.e., at the time one is queuing for an interest, then the Javanese would normally say "Sumangga Panjenengan Rumiyin 
Kemawon!", Or even if one feels disadvantaged by others, he would say "Sampun, sampun, boten menapa-menapa'.

The four releases following also illustrate the good character of humans

(23) Sabda amerta

(24) Milih papan

(25) Nganglang pringga

(26) Embat-embat calarat 'greeting water of life'

'choosing a place'

'patrolling danger'

'proposing for a crested-lizard'

The example (23) refers to individual's patient, understanding character, which in bebasan is described with sabda amerta 'his words (like) water of life'. People with patient characteristics speak words ( $s a b d a)$, the way they speak is soothing, like the cool water of life (amerta).

The context related to humans' good character is also revealed through texts in the form of Javanese saloka. This can be observed in the following four examples of saloka.

(27) Giri suci jaladri pawaka surya sasangka anila tanu 'mountain, holy, sea, fire, sun, moon, wind, body (subtle)'

(28) Dewa tan owah 'god does not change'

(29) Gendhon rukon 'a harmonious cocoon'

(30) Bumi pinendhem 'the buried earth'

The character of a good king is comparable to a mountain (giri) for it is sturdy, holy (suci) like clear water, forgiving like the sea (jaladri), the punisher like fire (pawaka), conscientious and calm like the sun (surya) and moon (sasangka), complete as the wind (anila), and be gentle (tanu), exemplified in saloka (27).

\section{Conclusion}

Javanese proverb is a typical Javanese language in use with various names, including paribasan, bebasan, saloka, pepindhan, sanepa, and isbat should interestingly be studied for its unique and specific nature. Proverbs function as decoration pieces, reinforcing intentions, and giving advice, teachings, and guidelines for human life. More specifically, Javanese proverb functions to describe the Javanese people's attitudes and characters amidst the social life of Javanese society.

The various human characters described in Javanese proverbs can be typically distinguished into two kinds, good characters and bad characters. The good characters, noble, and praiseworthy need to be emulated and take as the role model; on the contrary bad characters, despicable, and evil must be avoided.

In reality, the text is always related to the context, both the context of language and context beyond the language. Proverbs are a text while human characters are an outside the context. Human characters as contexts beyond the language represented through texts in proverbs. The Javanese proverb as part of the Javanese language functions as a persuasive social control. That is, it serves to control, therefore, people emulate and take the good character as the role model, character, behavior, and attitudes in their lives, in addition to avoid the bad character, trait, behavior, and attitudes referred to by the proverb. 


\section{References}

[1] E. Sulistyo, "Jokowi dan Kekuasaan Jawa," Harian Tempo, 2 Agustus 2019.

[2] G. Kusno, "Peribahasa Indonesia yang Perlu Digugat," Kompasiana.com, 17 Juni 2019.

[3] N. R. Setyaningsih, "Pepindhan tentang Aktivitas Manusia dalam Bahasa Jawa," $J$. Widyaparwa, vol. 44, no. 2, pp. 138-150, Desember 2016.

[4] Y. A. Satiyoko, "Wani Ngalah Luhur Wekasane, Pesan Moral Jawa dalam Novel Berbahasa Jawa Candhikala Kapuranta Karya Sugiarta Siwibawa: Sebuah Kajian Sosiologi Sastra," J. Widyaparwa, vol. 40, no. 1, pp. 1-11, Juni 2012.

[5] E. Setiyanto, "Wacana Hortatori Ular-Ular Bahasa Jawa: Kajian Slot dan Struktur Slot," $J$. Widyaparwa, vol. 40, no. 1, pp. 13-24, Juni 2012.

[6] N. Darheni, "Gaya Bahasa Perbandingan dalam Lirik Tembang Cianjuran: Ekspresi Karakter Masyarakat Sunda di Jawa Barat," J. Metalingua, vol. 14, no. 1, pp. 83-102, Juni 2016.

[7] R. Almos, Pramono, and Reniwati, "Pantun dan Pepata-Petitih Minangkabau Berleksikon Flora dan Fauna," J. Adabiyyat, vol. XIII, no. 2, pp. 301-317, Desember 2014.

[8] M. A. Khak, "Idiom dalam Bahasa Indonesia: Struktur dan Makna," J. Widyaparwa, vol. 39, no. 2, pp. 141-153, Desember 2011.

[9] H. Kridalaksana, Kamus Linguistik. Jakarta: PT. Gramedia, 1983.

[10] A. Triyono, Wedhawati, S. Widati, R. Indriani, and S. Arifin, Peribahasa dalam Bahasa Jawa. Jakarta: Departemen Pendidikan dan Kebudayaan, 1988.

[11] Tim Penyusun Kamus Pusat Pembinaan dan Pengembangan Bahasa, Kamus Besar Bahasa Indonesia, Edisi II C. Jakarta: Balai Pustaka, 1997.

[12] Sudaryanto, Menguak Fungsi Hakiki Bahasa. Yogyakarta: Duta Wacana University Press, 1990.

[13] M. Halliday and R. Hasan, Language, Context, and Text: Aspect of Language in a SocialSemiotic Perspective, Diterjemahkan ke dalam bahasa Indonesia oleh Asrudin Barori Tou, 1992. Bahasa, Konteks, dan Teks: Aspek-aspek Bahasa dalam Pandangan Semiotik-Sosial. Yogyakarta: Gadjah Mada University Press, 1985.

[14] F. Borgias, "Bahasa dan Realitas Perubahan Sosial," Basis, vol. XLII, no. 10, pp. 361-374, Oktober 1993.

[15] Sudaryanto, Metode dan Aneka Teknik Analisis Bahasa: Pengantar Penelitian Wahana Kebudayaan secara Lingual. Yogyakarta: Duta Wacana University Press, 1993.

[16] S.T. Widodo and K. Saddhono. "Petangan Tradition In Javanese Personal Naming Practice: An Ethnoliguistic Study." GEMA Online® J. of Lang. Stu. vol. 12 no. 4 pp 1165-1177, 2012 